\title{
A TEFL-Based Analysis of the Egyptian EFL Students' Production of Refusal and Acceptance Speech Acts
}

\section{Dr. Sahar Abdul Hameed Shishan}

Sheraton Higher Institute

Department of Languages \& Translation

Abstract

7 he present study measured the Egyptian EFL students' FL pragmatic competence in producing the refusal speech act. It aimed to determine the types of refusal strategies adopted by the Egyptian EFL students. In this regard, data were collected from 60 Egyptian EFL students. Participants were divided into two groups with 30 students each. Group A comprised students who are majoring in English and enrolled at the Department of English whereas group $B$ included students who studied English as an ESP course at the Department of Tourism. Data were collected using a 12-item Oral discourse completion task (Oral DCT) questionnaire. Data were analyzed by using descriptive statistics like frequencies, mean scores and percentages. One way analysis of variance (ANOVA) was conducted as well to judge statistical significance between contextual variables and categories of refusal and acceptance strategies. Findings indicated that Egyptian EFL learners varied in adopting acceptance strategies, however they tended to use similar strategies for refusing invitations. The study emphasizes the needs of teaching pragmatic behavior to Egyptian EFL tertiary students. Social contextual variables were found to have statistically significant influence on the selection of refusal and acceptance strategies adopted by Egyptian EFL students.

Keywords: refusal and acceptance strategies of invitation, Egyptian EFL undergraduates, L1 transfer, FL pragmatic instructions.

\section{Introduction}

Barron (2003), Schauer (2004) and Bardovi-Harlig (2010) defined pragmatics as an action of communication within the parameters of social context. Interlanguage 
pragmatics is that branch of pragmatics which is mainly concerned with how FL learners use the acquired knowledge of pragmatics. The realization of the speech act of invitation as performed by native speakers of English has been investigated in different cultures and languages as indicated in the literature review section. The different backgrounds of people who speak the same language may lead to misunderstanding and miscommunication. Thus, it is necessary to investigate into sociopragmatic transfer of EFL learners which means copying L1 cultural knowledge when performing an FL speech act. In addition, Kapser and Rose (2001) Kasper (2002) and clarified that L2 pragmatic competence is intricately entwined with the Communicate Language Teaching (CLT). Success in English language communication largely depends on developing the linguistic competences at the syntactic, morphological, phonological and lexical levels. However, FL instructors are aware that EFL learners who can produce grammatically and phonologically correct utterance may fail due to their undeveloped pragmatic competence. The term "pragmatic competence" refers to the extent EFL learners can manage to interpret and express certain communicative functions in certain communicative contexts. It was necessary, therefore, to examine how Egyptian EFL undergraduates can refuse and accept invitations in light of the Arabic culture and to address the element of teaching pragmatics to Egyptian EFL learners.

\section{Problem Statement}

The study was intended to be a cross-sectional study. It attempted to answer questions related to the description of FL pragmatics among Egyptian EFL learners in terms of using FL refusal and acceptance strategies. In other words, it described the frequency of using different types of refusal and acceptance strategies among the Egyptian EFL learners. It analyzed the Egyptian EFL learners' FL 
pragmatics in relationship with certain social variables, namely social distance and social status. It finally handled the point of FL pragmatic instructions to improve the awareness and development of FL pragmatics among Egyptian EFL learners.

\section{Aims}

The study fundamentally aimed to describe the strategies which Egyptian EFL learners adopt whenever they develop their use of FL pragmatics to express refusal and acceptance. The study also aimed to:

1. Determine the order and frequency of refusal and acceptance strategies used by Egyptian EFL learners.

2. Determine how influential the above mentioned social variables are on the development of the refusal and acceptance strategies among some Egyptian EFL learners.

3. Use the findings in drawing some teaching implications for FL pragmatic instructions in Egypt.

\section{Research Questions:}

1. How does the field of study affect the participants' performance in refusing and accepting invitation?

2. How does the refusal and acceptance of invitation vary among the two groups of participants based on the social distance?

3. How does the refusal and acceptance of invitation vary among the two groups of participants based on the social status?

4. What are the teaching implications that can be drawn for improving the Egyptian EFL students' performance in declining and accepting invitation?

\section{Significance of the study}

The study was considered significant since it provided an analysis of how Egyptian EFL learners used refusal and acceptance strategies in different situations which reflect different levels of social distance and social status. The 
study has a particular significance since it set a model for investigating other pragmatic strategies used by Egyptian and other EFL learners. That is, it can be applied to other EFL learners in different countries. The study provided teaching implications for the teaching of the FL pragmatic strategies in terms of refusal and acceptance strategies at the Egyptian Higher learning institutes.

\section{Limitations of the study}

This study was limited to measure the FL pragmatic production of sixty Egyptian undergraduates at the Sheraton Higher Institute and hence discussed the appropriate FL pragmatic instructions that can be taught to them and their counterparts at other higher learning institutes.

\section{Literature review}

Felix-Brasdefer (2003) Examined how the native speakers of Spanish apply politeness in refusing an invitation in comparison to American speakers of English who were advanced learners of Spanish. He collected data based on role plays from 30 participants divided into three groups. Findings indicated that social factors including social relation and the situation were crucial to the adoption of refusal direct strategies adopted by the participants. The advanced American learners of the Spanish language indicated positive and negative types of interlanguage transfer while declining invitations in the Spanish language. This revealed that participants were not familiar with the cultural values and norms of the target language and lacked the Spanish sociopragmatic competence which qualifies them to realize the Spanish-native speaker- like strategies when refusing invitations.

In a similar study, Rakowicz (2009) investigated how Polish speakers of English deal with vague ways of L2 invitation. Rakowicz analysed participants' responses to the 
way they do when speaking Polish and to the way American speakers of English adopt when responding to invitation. Rakowicz collected data from 56 participants divided into two groups. Whereas one group comprised 26 Polish speakers of English, the other group included 30 Americans. Data collected based on an open DCT consisting of six various situations on invitation. Findings indicated that Polish speakers of English tended to apply the Polish strategies when responding to vague invitation. Rakowicz emphasized that Polish interlanguage negative transfer impedes their realization of American-like invitation strategies. Similar to Rakowicz' study, Wang (2003) reported similar results when compared the invitation-declining strategies of both Chinese EFL learners and American speakers of English. The Chinese cultural-based responses to the English invitation scenarios showed significant Chinese interlanguage transfer into the Chinese EFL learners in a violation of the English L2 pragmatic norms spread among the American speakers of English.

Salmani-Nodoushan (2006) examined the strategies Persians used to apply in offering two kinds of invitations: unreal invitations and serious invitations. The study differentiated between these two types according to the features proposed by Clark and Isaac' study in 1990. Salmani-Nodoushan (2006, p.905) named these features as "pretense, mutual recognition, collusion, ambivalence, and off-record purpose".

Suzuki (2009) explained the pragmatic strategies which the American native speakers of English used politely when expressing the speech act of invitation. This study is, indeed, relevant to the fourth aim of the current study as it explains the indirect strategies which Americans adopt in refusing or accepting invitations. Such strategies provide a 
teaching model which FL instructors can use in teaching the pragmatic behavior to their Egyptian EFL learners. Suzuki collected data from American undergraduates through two different instruments, namely DCT and role plays. The linguistic analysis was carried out on the basis of lexis, grammar and discourse. This analytical approach differs from that adopted in the present study which is mainly based on the cultural values of the target language community. Suzuki's findings provided a corpus of materials that can be natural and useful for use through the English language teaching to non-native speakers of English in order to train them producing the speech act of inviting. Suzuki determined the polite forms of inviting adopted by the Americans. These forms include declarative, interrogative and conditional + want/ like/ would, etc.

In addition, several interlaguage studies were conducted on Arab EFL learners to indicate the impact of Arabic social and cultural norms reflected in their pragmatic output. AlIssa (2017) indicated the social and cultural values of Jordanian EFL learners reflected in their L2 English pragmatic performance. Al-Issa explained that according to the Arabs' cultures, Arabs used to exaggerate in praising their interlocutors as a means of pleasing them, strengthening ties among friends or even get money rewards for rendering services among strangers. Therefore, Jordanian EFL learners, tended to apply their culturally rooted norms by using elaborated sentences to justify their refusal and to avoid being misunderstood by their interlocutors. On the other hand, English native speakers prefer to use short semantic formulae to express their refusal.

Al-Eryani (2016) compared the Yemeni EFL learners' pragmatic performance to that of American native speakers 
of English. Findings indicated high level of interpragmatic transfer from the Arabic language into the Yemeni EFL learners performance in English pragmatics marked with the use of Arabic-based semantic patterns into English. Consequently, Yemeni EFL learners differed in their perception of the sequential order from the American native speakers of English in order to express refusal. The pragmalinguistic negative transfer was evident in the use of Yemeni EFL learners of the Arabic-based syntactic formula, which consists of 'can't' plus regret in order to express refusal. However, American native speaker usually tended to express their refusal by using the syntactic formula of 'no' plus regret. The Yemeni adopted formula of refusal was evidently adopted from their mother tongue striking an example of the negative interlanguage pragmatics. According to Al-Eryani social distance played as well a main role in determining the refusal strategies adopted by the Yemeni EFL learners. They are likely to use direct refusal strategy to interlocutors of lower social class status. On the contrary, American native speakers of English do not usually prefer to use direct refusal strategies. Rather, they use excuses and justifications as ways of indirect refusal strategies. Similarly, Al-Khatib (2006) proved the influence of Arabic culture and social values on the Jordanian EFL learners of English in adopting invitation strategies.

Hamouda (2014) discussed the refusal strategies which Saudi EFL learners chose to use in a response to suggestion, invitation and offer. The study was considered as a pragmalinguistic examination of such refusal strategies in the perspectives of social factors that could determine variation in adopting the refusal strategies on the one hand. On the other hand, Hamouda examined as well the impact of pragmatic instruction on developing the ability of Saudi 
EFL to use the speech act of refusal. The study also sought identifying the views of Saudi EFL learners regarding the use of explicit instruction as a means of teaching the English speech act of refusal. Hamouda divided the forty four participants into two groups. Both 'control' and 'treatment', according to terms used by Hamouda, comprised 22 participants. Participants were freshmen majoring in English language, enrolled at the Department of English, Qassim University, Saudi Arabia. All of them study English as a foreign language, and none of them stayed or been to a country where English is the mother tongue. They were taught a number of refusal-basedEnglish conversations adopted in the English book "Headway". Hamouda collected data through two written instruments; written DCT and a 'self report'. The written DCT contained 12 situations equally divided to cover suggestion, invitation and request with four situations each. All the 12 situations observed various kinds of social relations between the interlocutors. Participants were asked as well to write a 'self report' in order to ascertain the results of the DCT on the one hand and make an evaluation of the impact of explicit pragmatic instruction on developing the Saudi EFL learners' pragmatic performance. Hamouda reported that the development of Saudi EFL learners' pragmatic competence is attributed to the use of explicit pragmatic instruction. Saudi EFL learners have positive perception towards the teaching of pragmatics.

Bardovi-Harlig (2010) raised, for instance, some of these factors which are mostly related to pragmatic teaching process including the devised pragmatic input, L2 pragmatic instructions and other two important factors which are more related to ESL learners' exposure to L2 pragmatics and their L1 transfer into their L2 pragmatic output. In this regard, Barron (2003) argued that it is the 
position of English in a non-native speaking country which helps create the environment for better L2 pragmatic development. For example, in countries were English is used as a second language, on the contrary to those where English is used as a foreign language, L2 learners are more eligible to have L2 pragmatic input than the EFL learners because they have opportunities of language practice outside the classroom borders either with their native speakers teachers or even with other native speakers who exist in such countries like Singapore, Malaysia and India. On the other hand, Schauer (2004) found that staying in a L2-speaking environment gives some EFL learner a privilege to develop their L2 pragmatic competence over those EFL learners who have never been to any of the English native speaking countries.

Niezgoda and Rover (2001) pointed out that studying English in the mother-tongue environment does not enrich EFL learners' knowledge in pragmatics as much as it enriches their knowledge in English grammar. Learning English in a foreign language context does provide EFL learners with opportunities of intercultural communication and does not develop their L2 pragmatic competence due to the lack of proper pragmatic input. In a similar finding, Kasper and Rose (2002) indicated that having contacts with English native speakers does not often guarantee the provision of L2 pragmatic input. Meanwhile Taguchi (2008) diminished the importance of the environment role in enhancing the learners' L2 pragmatics which can be successfully developed over time within the first language learning context. As such Taguchi claimed that staying in native-speaking countries is not a prerequisite for L2 pragmatic development.

Other interlanguage pragmatic studies handled the role of L2 pragmatic instruction in developing the pragmatic 
competence of ESL learners (e.g. Takimoto, 2008; \& Bardovi-Harlig, 2013). These studies are based on the concept of potential teaching of pragmatic competence. In other words, ESL learners can be taught L2 pragmatics. In this regard, Rose (2005) clarified that even though pragmatic development may happen without L2 pragmatic instruction, but it consumes longer period of time than in the case of using L2 pragmatic instruction. Furthermore, EFL learners who received L2 pragmatic instruction perform better than those learners who did not. Tateyama (2001) and Takahashi (2005) found that using explicit L2 pragmatic instruction is more effective in developing ESL learners' pragmatic competence. On the other hand, Cook (2001) asserted that it the implicit L2 pragmatic instruction and not the explicit one which can highly develop the ESL learners' pragmatic competence. However, Soler (2005) and Koike and Pearson (2005) emphasized that the combination of both explicit and implicit types L2 pragmatic instruction is useful for the development of ESL learners' pragmatic competence. This helps develop ESL learners' awareness of L2 pragmatic norms and strategies; their use of discourse markers; and improve their metapragmatic knowledge.

\section{Conceptual framework}

In the present study, the conceptual framework is based on three of the four variables affecting the development of FL pragmatic competence as devised by Bardovi-Harlig (2013). These four variables are L1 culture including social distance and social status, FL linguistic competence, environment, and FL instructions. The present study focused only on social distance, social status, and FL instruction. In addition, the present study adopted the classification of refusal and acceptance strategies, which is summarized in Table 1, as devised by Salazar, Safont, and Codina (2009). 


\section{Methodology}

\section{Participants}

Sixty Egyptian EFL undergraduates participated in the study. They were divided into two groups with thirty students each. Group A comprised English language major students who are enrolled at the Department of Languages and Translation whereas group B included ESP students enrolled at the Department of Tourism.

Table 1: Distribution of social distance and status of the FDCT situations

\begin{tabular}{|c|c|c|c|}
\hline Situations & Type of Response & Social Distance & Social Status \\
\hline $\begin{array}{l}\text { 1. Your boss invites } \\
\text { you to the barbeque } \\
\text { party at his house. }\end{array}$ & Refusal & $-D$ & $\mathbf{S}>\mathbf{H}$ \\
\hline $\begin{array}{l}\text { 2. A friend invites } \\
\text { you to go to the } \\
\text { beach. }\end{array}$ & Refusal & $-D$ & $\mathbf{S}=\mathbf{H}$ \\
\hline $\begin{array}{l}\text { 3. A student invites } \\
\text { the senior lecturer to } \\
\text { go to a party. }\end{array}$ & Refusal & $-D$ & $\mathbf{S}<\mathbf{H}$ \\
\hline $\begin{array}{l}\text { 4. A salesman invites } \\
\text { the chairman of a } \\
\text { company to one the } \\
\text { expensive } \\
\text { restaurants. }\end{array}$ & Acceptance & $+D$ & $\mathbf{S}<\mathbf{H}$ \\
\hline $\begin{array}{l}\text { 5. A student invites } \\
\text { his/her dean } \\
\text { attend his/her Ph.D. } \\
\text { thesis defense }\end{array}$ & Acceptance & $-D$ & $\mathbf{S}<\mathbf{H}$ \\
\hline $\begin{array}{l}\text { 6. As a teacher, you } \\
\text { declined, your } \\
\text { students, invitation } \\
\text { to a picnic. }\end{array}$ & Refusal & $+\mathrm{D}$ & $\mathbf{S}<\mathbf{H}$ \\
\hline $\begin{array}{l}\text { 7. A professor invites } \\
\text { a university teacher } \\
\text { to attend a seminar. }\end{array}$ & Acceptance & $+\mathrm{D}$ & $\mathbf{S}>\mathbf{H}$ \\
\hline $\begin{array}{l}\text { 8. A friend invites } \\
\text { you to dinner as you } \\
\text { will travel tomorrow } \\
\text { for another state. }\end{array}$ & $\begin{array}{l}\text { You accept the } \\
\text { invitation }\end{array}$ & $-D$ & $\mathbf{S}=\mathbf{H}$ \\
\hline $\begin{array}{l}\text { 9. } \\
\text { invitation }\end{array}$ & Refusal & $+\mathrm{D}$ & $\mathbf{S}=\mathbf{H}$ \\
\hline $\begin{array}{l}\text { 10. Your supervisor } \\
\text { invites you for lunch }\end{array}$ & Acceptance & $-D$ & $\mathbf{S}>\mathbf{H}$ \\
\hline $\begin{array}{l}\text { 11. Your newly } \\
\text { appointed boss on } \\
\text { his first day in office } \\
\text { invites you to a } \\
\text { warming party. }\end{array}$ & Refusal & $+\mathrm{D}$ & $\mathbf{S}>\mathbf{H}$ \\
\hline $\begin{array}{l}12 . \quad \text { A } \\
\text { appointed } \\
\text { staff at } \\
\text { your } \\
\text { invites for dinner. }\end{array}$ & Acceptance & $+\mathrm{D}$ & $\mathbf{S}=\mathbf{H}$ \\
\hline
\end{tabular}




\section{Data Collection}

\section{Instrument}

The oral DCT was designed to include 12 situations which are adopted and adapted from several ILP studies like for each of $\mathrm{S}<\mathrm{H}, \quad \mathrm{S}>\mathrm{H}$, and $\mathrm{S}=\mathrm{H}$.

Barron (2003), Honglin (2007), Schneider and Barron (2008), and Linde (2009). An Arabic-translated version of the oral DCT was used. It was mainly intended to the Tourism-majoring participants to ensure their full understanding of the instructions and the included situations of invitation. Situations were designed based to the classification of the contextual variables of social distance and social status. Social distance (D) is of binary value; it means to extent both interlocutors know each other. When the interlocutors know each other, the social distance is symbolized as (-D). However, the symbol (+D) indicates that the interlocutors do not know each other. Among the 12-situation oral DCT, six situations indicated that the interlocutors are familiar to each other or know each other (- D). On the other hand, six situations indicated that the interlocutors do not know each other $(+D)$. According to Schneider and Barron (2008), social power is of two types: symmetrical or asymmetrical. In other words, the interlocutors are either equal or unequal in their social status. The inviter (speaker) symbolized as (S) can have higher social status than the invitee (hearer) symbolized as $(\mathrm{H})$. This social status is expressed as $\mathrm{S}>\mathrm{H}$. When the invitee is higher in his/her social status than the inviter, it is expressed as $\mathrm{S}<\mathrm{H}$. When both the inviter and the invitee have the same social status, it is expressed as $\mathrm{S}=\mathrm{H}$. The 12 situations equally indicated the different categories of the social status. That is, four situations

\section{Procedures of data collection}

Data were collected in two sessions with each session lasted for an hour. Data were collected from each group of 
participants in a separate session. That is, a session for data collection from the English-majoring students. Another session was conducted to collect data from the Tourismmajoring participants. In the two sessions of data collection, participants were briefed on the oral DCT as they were orally informed about its instructions. Moreover, a pilot study was conducted on ten participants including 5 English-majoring and 5 Tourism-majoring students. The pilot study aimed to determine the reliability of the oral DCT where the Cronbach Alpha coefficient was 0.94 suggesting high reliability. In addition, the pilot study amended the wording of some situations to ensure better understanding on the part of participants.

\section{Data Analysis}

Statistically, the present study relied on descriptive statistics and one way analysis of variance (ANOVA). The descriptive statistics introduced the frequencies, mean scores and percentages of the different types of refusal and acceptance strategies employed by the participants in responding to the 12-situation oral DCT. Furthermore, one way analysis of variance (ANOVA) was adopted to indicate the statistical significance between the social distance and social status on the one hand and the participants' refusal and acceptance strategies on the other hand either within or among the groups of participants.

\section{Findings}

How does the field of study affect the participants' performance in refusing and accepting invitation?

Table 2 introduced the descriptive statistics of the refusal and acceptance strategies employed by the two groups of participants. Table showed Acknowledgement was the highest acceptance strategy adopted by group A $(75 \%)$ and group B (83\%). Although English-major participants in group A and those Tourism-majoring students in group B were roughly similar in using 
acknowledgement and gratitude, they had different performance in using positive opinion $(50 \%$ for group A while it was not used at all by group B) and well-wishing

Table 2: Descriptive statistics of refusal and acceptance responses by English and Tourism majoring participants

\begin{tabular}{|c|c|c|c|c|c|c|c|c|}
\hline Group & Acceptance & $\mathrm{F}$ & $\%$ & $\mathrm{M}$ & Refusal & $\mathrm{F}$ & $\%$ & $\mathrm{M}$ \\
\hline \multirow{10}{*}{ G A } & Indirect & & & & Direct & & & \\
\hline & Acknowledgement & 9 & 75 & 3 & $\begin{array}{c}\text { Negative } \\
\text { ability }\end{array}$ & 9 & 75 & 3 \\
\hline & Checking & 2 & 8.3 & 0.2 & $\begin{array}{c}\text { Indirect } \\
\text { regret }\end{array}$ & 9 & 75 & 3 \\
\hline & Gratitude & 7 & 60 & 3 & Wish & 2 & 16.6 & 0.6 \\
\hline & Idiom & 2 & 16.6 & 0.6 & Explanation & 12 & 100 & 4 \\
\hline & Offer & 4 & 33.3 & 1.3 & Gratitude & 4 & 33.3 & 1.3 \\
\hline & Solidarity & 1 & 8.3 & 0.3 & Joke & 1 & 8.3 & 0.3 \\
\hline & Positive opinion & 6 & 50 & 2 & & & & \\
\hline & Suggestion & 1 & 8.3 & 0.3 & & & & \\
\hline & Well Wishing & 4 & 33.3 & 1.3 & & & & \\
\hline \multirow{8}{*}{ G B } & Direct & 1 & 8.3 & 0.3 & Direct & & & \\
\hline & Indirect & & & & $\begin{array}{c}\text { Negative } \\
\text { ability }\end{array}$ & 5 & 41.6 & 1.6 \\
\hline & Acknowledgement & 10 & 83 & & $\begin{array}{c}\text { Indirect } \\
\text { regret }\end{array}$ & 4 & 33.3 & 1.3 \\
\hline & Checking & 3 & 17 & 0.5 & Explanation & 12 & 100 & 4 \\
\hline & Gratitude & 6 & 50 & 2 & Gratitude & 1 & 8.3 & 0.3 \\
\hline & Solidarity & 1 & 8.3 & 0.3 & & & & \\
\hline & Well-wishing & 2 & 16.6 & 0.6 & & & & \\
\hline & & & & & & & & \\
\hline
\end{tabular}

(33.3\% for group A and $16.6 \%$ for group B). Englishmajor EFL participants largely differed from their Tourism-majoring counterparts in adopting the acceptance strategy of well-wishing (33.3\% for the former and 16.6\% for the latter). Whereas English-major Egyptian EFL students used positive opinion strategy to indicate their acceptance $(50 \%)$, Tourism-majoring participants were unaware of such strategy as they did not use at all. 
Concerning refusal, the two groups' participants were similar in accounting for refusing invitations. The highest refusal strategy employed by participants of the two groups was explanation. The refusal performance of Englishmajoring participants was distinguished from their Tourism-majoring counterparts in using joke as a refusal strategy $(8.3 \%)$. Both groups of participants similarly adopted regret and direct negative ability as the second and third highest refusal strategies. This finding is similar to those reported by Al-Issa (2017), but contradicted Hamouda's (2014) findings. Remarkably, the refusal performance of all participants did not include the use of refusal strategies like pause fillers, promise for future acceptance, well-wishing and positive opinion. This finding raised a question on the necessity of training Egyptian EFL learners on using refusal strategies adopted by native speakers.

L1 transfer was evident in the responses of Egyptian EFL participants in both groups A and B. For examples, they used Arabic words like "inshallah" (God willing), "waallah" (by God), "Allah yabariklk "; a well-wishing sentence in Arabic which means "May Allah bless you". Thus, it is necessary for FL instructors to pay the attention of their EFL students to abandon the use of some Arabic idioms when declining or accepting invitations in English. There is a similarity between this finding and those findings reported by Wang (2003), Al-Eryani (2016) and Rakowicz (2009).

How does the refusal and acceptance of invitation vary among the two groups of participants based on the social distance and social status?

The employment of one way analysis of variance (ANOVA) aimed at determining the statistically significant influence social distance and status may have on the 
number of refusal strategies among the two groups. Tables $3,4,5,6,7$ and 8 indicated that the social distance and status have statistically significant influences on the use of refusal strategies within each group and among the two groups of participants at the 0.05 level. The finding emphasized the importance of teaching the underlying cultural components of pragmatic behavior adopted by the English native speakers to Egyptian EFL students. The finding is consistent with those reported by Al-Khatib (2006) and Al-Eryani (2016).

Table 3: Influence of $S<H(D+)$ on refusal responses among English and Tourism majoring participants

\begin{tabular}{|c|r|r|r|c|r|}
\hline & \multicolumn{1}{|c|}{$\begin{array}{c}\text { Sum of } \\
\text { Squares }\end{array}$} & df & Mean Square & F & Sig. \\
\hline Between Groups & 260.256 & 3 & 87.421 & 218.654 & .001 \\
Within Groups & 5.216 & 57 & .411 & & \\
Total & 265.472 & 60 & & & \\
\hline
\end{tabular}

Table 4: Influence of $S<H$ (D-) on refusal responses among English and Tourism majoring participants

\begin{tabular}{|c|r|r|r|r|r|}
\hline & \multicolumn{1}{|c|}{$\begin{array}{c}\text { Sum of } \\
\text { Squares }\end{array}$} & df & Mean Square & F & Sig. \\
\hline Between Groups & 266.753 & 2 & 127.944 & 64.570 & .002 \\
Within Groups & 22.456 & 58 & 1.953 & & \\
Total & 289.209 & 60 & & & \\
\hline
\end{tabular}

Table 5: Influence of $\mathrm{S}=\mathrm{H}(\mathrm{D}+)$ on refusal responses among English and Tourism majoring participants

\begin{tabular}{|c|r|r|r|r|r|}
\hline & \multicolumn{1}{|c|}{ Sum of } & df & Mean Square & F & Sig. \\
\hline Squares & 183.620 & 2 & 87.255 & 10.437 & .002 \\
Within Groups & 92.808 & 58 & 8.273 & & \\
Total & 276.430 & 60 & & & \\
\hline
\end{tabular}


Table 6: Influence of $S=H(D-)$ on refusal responses among English and Tourism majoring participants

\begin{tabular}{|c|r|r|r|r|r|}
\hline & \multicolumn{1}{|c|}{$\begin{array}{c}\text { Sum of } \\
\text { Squares }\end{array}$} & $\mathrm{df}$ & Mean Square & \multicolumn{1}{|c|}{$\mathrm{F}$} & Sig. \\
\hline Between Groups & 173.938 & 2 & 87.925 & 10.562 & .002 \\
Within Groups & 89.500 & 58 & 8.135 & & \\
Total & 263.438 & 60 & & & \\
\hline
\end{tabular}

Table 7: Influence of $\mathrm{S}>\mathrm{H}(\mathrm{D}+)$ on refusal responses among English and Tourism majoring participants

\begin{tabular}{|c|r|r|r|r|r|}
\hline & \multicolumn{1}{|c|}{$\begin{array}{c}\text { Sum of } \\
\text { Squares }\end{array}$} & df & Mean Square & F & Sig. \\
\hline Between Groups & 267.865 & 2 & 120.264 & 313.856 & .001 \\
Within Groups & 4.771 & 58 & .453 & & \\
Total & 272.636 & 60 & & & \\
\hline
\end{tabular}

Table 8: Influence of $S>H$ (D-) on refusal responses among English and Tourism majoring participants

\begin{tabular}{|c|r|r|r|r|r|}
\hline & \multicolumn{1}{|c|}{ Sum of } & df & Mean Square & F & Sig. \\
\hline Squares & & & & .001 \\
Between Groups & 261.754 & 2 & 128.822 & 43.514 & \\
Within Groups & 28.676 & 58 & 2.677 & & \\
Total & 290.430 & 60 & & & \\
\hline
\end{tabular}

\section{Teaching implications}

What are the teaching implications that can be drawn for improving the Egyptian EFL students' performance in declining and accepting invitation?

There is no doubt that FL instructors at the Sheraton Higher Institute should be familiar with the meaning of pragmatics in order to be able to select pedagogically oriented activities addressing the needs for developing the FL pragmatic competence of their students. This entails knowledge of which FL pragmatic aspects should be taught and why FL pragmatics should be taught as well. In this concern, Celce-Murcia (2007) urged FL instructors to familiarize their students with the fundamental FL cultural 
variables of a certain communicative action because these variables affect their choices of specific linguistic formulas. These cultural variables are not only restricted to age, gender or social class affiliation, but also include the native-speakers' norms, values and beliefs. As such, Egyptian EFL undergraduates need to be exposed and taught the same linguistic choices adopted by the native speakers. This entails paying attention to the teaching of conversation at the Department of Languages and Translation where conversation is one of the core courses and at the Department of Tourism where English is taught as an ESP course.

In addition, the FL cultural values of a communicative action should be taught to Egyptian EFL undergraduates as well. This entails exposing them to the FL cultural facts. For instance, Egyptian EFL undergraduates should be taught how to use the native speakers' indirect strategies of refusal like 'promise future', 'positive opinion' or 'hedging' and their acceptance strategies like 'checking', 'solidarity', or 'well-wishing'. This task can be fulfilled through various relevant listening and speaking activities to refusing and/or accepting invitation. In this regard, Brown (2007) and Sanz and Leow (2011) explained that FL instructors should not explicitly make Egyptian EFL undergraduates familiar with learning FL pragmatic competence. This approach is consistent with CLT which is theoretically based on internalized knowledge rather than on the explicit teaching of language forms. This approach also enhances the fluency of Egyptian EFL undergraduates because it is an essential component of FL teaching.

Hofstede, Hofstede and Minkov (2010) pointed out that FL instructors may encounter a challenge in teaching the FL culture because of the heterogeneous nature of FL and L1 cultures. Culture as such can be divided based on 
the principles of individualism and collectivism or high and low social distance. Thus, Egyptian EFL undergraduates should be taught that English native speakers usually adopt formal indirect and more elaborated strategies for communication. They could be also taught to abandon the use of some Arabic idioms while expressing their refusal or acceptance like 'Allah yabriklk' (May Allah bless you) or 'Inshalla' (God willing). As such, FL instructors are required to develop culturally-based materials for teaching the FL pragmatic behaviour.

\section{Conclusion}

In spite of the fact that English-major Egyptian EFL participants in group A and those ESP Egyptian students were relatively similar when expressing acknowledgement and gratitude, they deeply differed when using positive opinion. They also deeply differed in using the acceptance strategy of well-wishing. On the contrary to English-major Egyptian EFL students, ESP Egyptian participants were unfamiliar with using the positive opinion strategy when expressing acceptance of invitations. Both English-major Egyptian EFL students and ESP Egyptian students used similar strategies of refusal and provided reasons for refusing invitations. The study proved that Egyptian EFL undergraduates were in a need for learning the English native speakers' refusal strategies.

The present study stressed the importance of teaching FL pragmatic behavior to Egyptian EFL undergraduates. Teaching FL pragmatics should not be explicitly taught, but it should be rather based on internalized knowledge. Egyptian EFL undergraduates should be familiar with using the English native speakers' indirect, formal and more elaborated strategies. They should be also taught to 
discard the use of some Arabic idioms while expressing refusal or acceptance of invitations.

\section{Suggestions for further research}

Below are some suggestions for further research:

1. A study can be carried out to examine the other two contextual variables which the present study did not investigate, namely environment and FL linguistic competence.

2. The present study can be replicated using other speech acts like requesting, complaining, complimenting, greeting etc.

3. A study can be conducted to investigate the sociolinguistic and sociocultural variables affecting the communicative behavior of English native speakers.

4. A study can be carried out to discuss how FL instructors can devise target language community culturally-based activities for teaching pragmatics.

5. It is also appropriate to investigate the FL instructors' familiarity with FL cultural values, norms and beliefs.

6. An analytical study can be conducted to discuss the Egyptian EFL learners' FL pragmatic output in line with Brown and Levinson's (1987) politeness theory.

7. It is also appropriate to investigate the positive and negative Arabic transfer into the linguistic formulas of Egyptian EFL learners' FL pragmatic output.

\section{References}

Al-Eryani, A. (2016). Cultural awareness and its Role in pragmatic competence: A study in EFL. Thamar University Journal for Studies and Research, Volume No.21, 2016.

Al-Issa, A. (2017). English as a medium of instruction and the endangerment of Arabic literacy: The case of the United Arab Emirates. Arab World English Journal, 8(3), 3-17.

Al-Khatib, M. A. (2006). The pragmatics of invitation making and acceptance in Jordan society. Journal of Language and Linguistics 5(2), 272-294. 
Bardovi-Harlig, K. (2006). Interlanguage development: Main routes and individual paths. AILA Review, 19, 69-82.

Bardovi-Harlig, K. (2010). Pragmatics and second language acquisition. In R. Kaplan (Ed.) The handbook of applied linguistics, (2 $2^{\text {nd }}$ ed 232-243). Oxford, UK: Oxford University Press.

Bardovi-Harlig, K. (2013). Developing L2 pragmatics. Language Learning, 63, (1), 68-86.

Barron, A. (2003). Acquisition in interlanguage pragmatics: Learning how to do things with words in a study abroad context. Amsterdam/Philadelphia: John Benjamines.

Brown, H. D. (2007). Teaching by principles: An interactive approach to language pedagogy (3rd ed.). White Plains, NY: Pearson Education.

Celce-Murcia, M. (2007). Rethinking the role of communicative competence in language teaching. In E. Alcón Soler and M. P. Safont Jorda (Eds.), Intercultural language use and language learning (pp. 41-57). Dordrecht, Netherlands: Springer.

Cook, H. M. (2001). Why can't learners of JFL distinguish polite from impolite speech style, In K.R Rose and G. Kasper (eds.). Pragmatics in Language Teaching. New York: Cambridge University Press, 125-144.

Felix-Brasdefer, J.C. (2003). Declining an invition: A crosscultural study of pragmatic strategies in American English and Laain American Spanish. Multilingua, 22, 225-255.

Hamouda, A. (2014). The effect of explicit instruction on developing Saudi EFL learners' pragmatic competence in refusal formulas. Research Journal of English Language and Literature (RJELAL), 2, (1), 138-160.

Hofstede, G., Hofstede, G. J., \& Minkov, M. (2010). Cultures and organizations: Software of the mind: Intercultural cooperation and its importance for survival. New York, NY: McGraw-Hill.

Honglin, L. (2007). A Comparative Study of Refusal Speech Acts in Chinese and American English. Canadian Social Science, 3

(4) available online at:http://escanada.net/index.php/css/ article/download/i.css.1923669720070304.014/440

Kasper, G. (2000). Pragmatics in language teaching: Why and how it should be taught. Osaka: Kansai University.

Kasper, G., and Rose, K. R. (2001). Pragmatics in Language Teaching. Cambridge: Cambridge University Press.

Kasper, G. and Rose, K. (2002). Pragmatic development in a second language. Malden, MA: Wiley Blackwell. 
Koike, D. A., and Pearson, Lynn, (2005). The effect of instruction and feedback in the development of pragmatic competence. System, 33: 481-501.

Linde, Á. (2009). How polite can you get? A comparative analysis of interlanguage pragmatic knowledge in Spanish and Moroccan EFL university students. PortaLinguarum: Revistainternacional de didáctica de laslenguasextranjeras, 12, 133-148.

Niezgoda, K. and Roever, C. (2001). Pragmatic and grammatical awareness: A function of the learning environment, In K.R. Rose and G. Kasper (eds.). Pragmatics in Language Teaching. Cambridge: Cambridge University Press, 63-79.

Rakowicz, A. (2009). Ambiguous invitations: The interlanguage pragmatics of Polish English language learners. New York: VDM Publishing House.

Rose, K. R. (2005). On the effects of instruction in second language pragmatics. System, 33: 385-399.

Salazar-Campillo, P., Safont-Jordà, M. P. and Codina-Espurz, V. (2009).

Refusal strategies: A proposal from a sociopragmatic approach. $R æ L:$

Revista Electrónica de Lingüística Aplicada, 8, 139-150.

Salmani-Nodoushan, M. A. (2006). A comparative sociopragmatic study on ostensible invitations in English and Farsi. Speech Community, 48, 8, 903-912.

Sanz, C. and Leow, R. P. (Eds.). (2011). Implicit and explicit language learning: Conditions, processes, and knowledge in SLA and bilingualism. Washington, DC: Georgetown University Press.

Schauer, G. A. (2004). May you speak louder maybe? Interlanguage pragmatic development in requests. EUROSLA Yearbook 4: 253-272.

Schneider, K and Barron, A. (Eds.) (2008). Variational Pragmatics: A Focus on Regional Varieties in Pluricentric Languages. Amsterdam/Philadelphia: John Benjamins.

Soler, E. A. (2005). Does instruction work for learning pragmatics in the EFL context? System, 33, 417-435.

Suzuki, T. (2009). How can American university students "invite" others? A corpus based study of linguistic strategies for the speech act of invitations. A paper presented at the $11^{\text {th }}$ Annual Conference of Pragmatics Society of Japan, held at Matsuyama University (Matsuyama, Ehime), $20^{\text {th }}$ DEC., 2008. 
Taghuchi, N. (2008). Pragmatic competence. New York: Mouton de Gruyter.

Takimoto, M. (2008). The effects of deductive and inductive instruction on the development of language learners' pragmatic competence. The Modern LanguageJournal, 92(3), 369-386.

Takahashi, S. (2005). Pragmalinguistic awareness: Is it related to motivation andproficiency? Applied Linguistics, 26(1): 90120.

Tateyama, Y. (2001). Explicit and implicit teaching of pragmatic routine:Japanese sumimasen, In K.R Rose and G. Kasper (eds.). Pragmatics in Language Teaching. New York: Cambridge University Press, 125-144.

Wang, Y. (2003). Refusal strategies in American and Chinese cultures: A comparative study, Retrieved on July 14, 2015 from http://deal.ohiostat.edu 